\title{
Lingua-Semantic Issues of Economic Texts
}

\section{Firuza Karimova ${ }^{1}$}

\author{
${ }^{1}$ Azerbaijan State University of Economics \\ 135 Hasan Aliyev Street, Baku, Azerbaijan
}

DOI: $10.22178 /$ pos.67-4

LCC Subject Category:

PE1001-1693

Received 16.01.2021

Accepted 26.02.2021

Published online 28.02.2021

Corresponding Author:

aim.2021@mail.ru

(C) 2021 The Author. This article is licensed under a Creative

Commons Attribution 4.0

License @ (1)

\begin{abstract}
There are various types and subtypes of scientific texts, depending on their designation and the relevance to different fields. Above all, the unique scientific texts intended for professionals and the texts written in scientific and business style for mass readers are mentioned. Each of them has got an informative function. The most widespread and essential system in a functional signalling system is language. Words should be motivated for people to assimilate the language and remember its signs. The study of the history of languages shows that the motivation of language signs in the early development of languages, the imitation of sound and imitation of an image are observed more sharply in words. In language, the sign has got the semantic, morphological and phonetic motivation. The motivation of language signs creates functional styles. Each text should the priority bear the characteristics of any style. For studying the lingosemantic features of the economic texts, it is first and foremost necessary to investigate their stylistic possibilities and terminological system. The forms of speech in language manifest themselves in the form of functional styles. The number and nature of the styles are mentioned differently. The artistic, scientifictechnical and formal-business styles among them are considered to be the main functional styles. The language of economic texts belongs to the business style; however, at the same time, the factor of using the terminological lexicon inherent in the scientific style forms the core of economic texts.
\end{abstract}

Keywords: linguistics; terminology lexicon; informative function; scientific style; economic texts.

\section{INTRODUCTION}

Each text should be selected by expressing its content in a logical sequence. Scientific texts are mainly realized in written form. However, at conferences, symposiums and other scientific meetings, these texts can be implemented orally. The economic texts, which are the leading example of business style, are also found mainly in written language. Documents related to such areas as state-building, politics, diplomacy, commerce, law and so on belong to formal-business texts. The primary function of such texts is to provide information. As a rule, these texts are available in the written form. The followings are mainly considered the business-style texts: office documents, government decrees, the parliamentary and presidential decrees, laws, orders, diplomatic documents, official correspondence, codes, the documents related to the constitution, education and medicine, trade agreements, communication documents, military documents, the agriculture, field regulations, instructions and guidelines, correspondence of various departments and ministries, recommendations, letters, applications, orders and minutes, acts, characteristics, credentials, references, presentations, commitments, contracts, etc.

Considering the diversity of these documents, each's lexical and grammatical features can divide the business style into sub-styles - the branches related to diplomacy, law, education, communication, trade, etc. Even though each of these substyles has its characteristics, the development of individual words and phrases and syntactic constructions connect them with the general requirements of the business style. Author [8] notes that the business style is distinguished from other styles, primarily by its linguistic features and examples of different styles. He indicates that, along with characterizing a specific style, several terms and words can be used in other styles. The development of appropriate terms in the business style's branches gives accuracy and clarity to the language of documents related to this style. The 
author [8] attributes the business style to purely office correspondence, style of legal-judicial papers, education, trade, communication, agriculture, official diplomatic documents, and parliamentary decisions and shows that "each of them has its specific lexical system".

Among the examples of lexis used in the business style, authors [8] mentions the followings: manager, financier, businessman, currency, currency exchange market, license, shareholder, joint-stock company, small enterprise, joint venture, trading company, shopping centre, commercial bank, conversion, revolving currency, payment, payment account, deposit bank, a national bank, state bank, income, accountant, chief accountant, balance sheet, budget balance, the balance of payments.

It is also noted that small groups of lexical names are part of the business style. Afterwards, the linguistic, grammatical (morphological), syntactic features of the business style are considered.

The language of economic texts belongs to the field of activity of scientific-technical and formalbusiness functional styles. There are similarities and differences between one language's functional styles and the functional styles of different languages.

The author [1] divides the stylistics into two parts: the lingua stylistics and belles-letters style. Even though there are two aspects of the same problem, it is necessary to distinguish them.

The researcher [5], taking the stylistics in a broader sense, identifies three main areas of research: 1) "Language style or structural style that is a "system of systems" (spoken, scientific, business, publicists, formal-office, etc.); 2) the style of speech, that studies the characteristics of different semantic and expressive genres of oral and written speech; 3) the stylistics of fiction - the art style that studies the style of all elements of the work of art, the individual style of the writer. According to [3] "...The stylistics is the field of linguistic science about the laws used to influence people subjectively in specific communicative speech situations of language".

The main areas of textual linguistics are the functionality of text categories and the specificity of their implementation in the language; for example, the category of modality, category of informativity, sub-textuality, etc., are the issues studied by text linguistics. This style does not go beyond the standard forms formed in the process of historical evolution. Therefore, archaic lexis and the old syntactic constructions can be preserved for a long time in this style. The formal-business style is associated with the traditions of statehood and independence. The influence of the pre-independence Arabic, Persian and then Russian languages did not allow the full functioning of this style and damaged its nationality. The Azerbaijani state's independence, the transformation of the mother tongue into state language in a real sense, has expanded the formal-business style's functional capabilities. The formal-business style includes the language of a) formal and b) business documents.

\section{MATERIALS AND METHODS}

Official documents are the formal documents compiled by state or governmental organizations in a particular order, in other words, approved by the signature of the authorized person, seal, etc. The specialists prepare these documents; these documents are discussed and adopted at various levels. The official documents have important legal content and are of historical significance; they regulate interstate and intra-state relations.

The economic texts are also one of the types of official business documents. Maximum perfection is expected in the economic texts; attention is paid to the unambiguousness, clarity and legal basis of the idea. The economic texts are divided into sections, articles, paragraphs according to their structure.

Not all the economic texts are of particular state importance. The official documents are usually relatively small in volume. Each person can prepare a specific part of business documents, while the official documents, as a rule, are prepared by specialists.

The specialists prepare economic texts. These documents are discussed and adopted at various levels. In this style, the idea is presented in standard forms and in a very concise way. This is precisely the main characteristic feature of the style. Formal-business style is the same, the standard for everyone. The figurative expressions or individual speech features are not encountered here. The national formal-business style was formed later than other functional styles.

The vocabulary of this style is compact, and the syntax is limited. Some archaic words and outdated syntactic patterns have been preserved for a long time in the official-business style. 
Each speech belongs to an individual functional style; nevertheless, the signs of different styles manifest themselves. This situation is also observed in the economic texts. Both the scientific and publics are observed in this type of texts. The linguistic expression of official and business documents is called the formal-business style. The main feature of this style is the concise presentation of ideas in standard forms. In this style, the words and figurative expressions are no longer used; the individual elements of speech are avoided; the vocabulary is concise. However, the syntax is limited. The normality is strong.

The decrees and decisions are characterized as a branch of official documents related to business style among the economic texts. The decisions consist of two parts. The first part is criticized this or that shortcoming. In this regard, the verb's negative form is used more at the beginning than at the end of the decisions. After indicating certain shortcomings in the decisions, the instructions given for their elimination are mainly in the verb's affirmative form.

The vocabulary and style of business documents are closely related to the issues they cover. Some of the words and expressions belonging to vernacular speech are not used in them. One of the main features of their language is that their linguistic composition is small and specific. There is no place for more explanation or description in this language. The words do not deviate from their nominative meanings.

Economic texts developed in a business style show different lexical composition depending on the content. For example, if the decision deals with banks, then the terms related to banking are often used.

Vocabulary is one of the main factors that differentiate styles. Depending on the document's specific content and the purpose for which it is set, the specific words are rarely used or never used in any other style. However, there are many words used in many functional styles of literary language, as well. These are lexical units that belong to the main vocabulary of the vernacular speech, and they take part in the formation of the literary language. Unlike official documents, the business documents are not of particular state importance but serve to express this specific issue. Our observations and conclusions on official business documents' language give grounds to say that the word combinations used in the language of documents acquire terminological status over time. At the beginning of each text is given a heading that describes its content. The title is the key element of the document.

We also consider it essential to say that a language unit that reflects a business style's characteristics is mainly syntactic units.

The words related to the formal-business style are given both using enumerations and by demonstration: to inform, to confirm, to assign, to take into account, and so on. We can indicate the declarative and command sentences from the types of sentences used in the language of official business documents. Speaking of the linguistic features of the business style, it should be noted that in this style as a whole and its sub-styles - some of the standards that exist in the language, standardized expressions and forms are often used. For example, to decide, to submit, to demand, to sign, to provide, to accept, to report, to vote for (against), to take action, to discuss, to put forward, to implement, to carry out, to involve, to use, to reward, to establish, to envisage, to take responsibility for, to enter into force, to expire, to prohibit, to bring to notice, to warn, etc.

This group of ready-made expressions in a business style ensures that the documents' language provides a clear and easy understanding. By the way, it should be noted that, in addition to certain fixed word combinations used in a business style (for example, to take action, to enter into force, to be invalid, to be responsible, etc.), phraseological combinations, metaphors, means of artistic expression, artistic comparisons, epithets, repetitions are usually not used. This is one of the main factors that distinguishes it from the artistic style.

Existing writings on business style have so far generally focused on its lexical and syntactic features. The observations show that, like other literary language styles, some morphological features in the business style are no less critical in the characterization and formation of this style. Some aspects of the use of nouns and verbs in businessstyle economic texts are noteworthy. The importance of frequent use of economic terms is one of the morphological features of business style.

In the economic half-style of business style, the use of derivative nouns and compound nouns formed by the repetition of the same word is encountered very rarely. It is also clear from observations that in the development of nouns, termword combinations, noun-dominants also play a role in characterizing the business style. These are 
specific for the language of various documents involved in semi-styles.

Although the telephone and computer networks dominate the delivery of information in our modern and globalized world, correspondence is the most common business communication type. In advertising activities, the delivery of commercial offers an ordinary letter is invaluable, as it can give an initial description, initial characteristic of the company's partners.

The issue of translating economic texts is also sparking interest. The following principles should implement the translation of economic texts: a) the practical purpose of the translated text must be taken into account; b) the pragmatic intention of the author of the text must be reflected in the translation; c) the level of the addressee (reader, listener) provided in the text should be taken into account.

The translation should adhere to the pragmatic nature of the original. Both similarities and differences between the English and Azerbaijani languages' lexical systems and grammatical structures manifest themselves. When translating economic texts from Azerbaijani into English, it is necessary to refer to the similarities between them and find an adequate expression of the incompatible components.

In economic texts, calque (semantic borrowing) is the primary translation method for enriching terminology. We can give an example of the lexical units included in the Azerbaijani language by the calque method. For example, we can give as an example such words as assortment, assortment diversity, a unit of weight, revenues from a sale (profit), hard-to-find items (scarce goods), and production costs (volume of current consumption). It should be noted that some of these units (sales revenue, hard-to-find items) are of descriptive type. The calque requires the preservation of the original example's motive, and the translation requires the availability of ready-made language tools in the target language.

Another method is interpreted as keeping the first part of the phrase and being translated the second part: tariff schedule and exchange goods. In our opinion, the first term can also be given in the form of a tariff network.

In the translation of economic texts, the author should present how he is accustomed to a foreign language group while maintaining his main pragmatic intention. It should be strongly emphasized that the translation of economic texts should be based on a concise description of the text. All other issues, in other words, its functional, stylistic, emotional characteristics and features, cannot be given without expressing the content of the text since all the other content components of the news are stratified over the primary information extracted from it and transformed into figurative associations. The translation of official documents from Russian into Azerbaijani also played a specific role in forming business style in the Azerbaijani language. At this time, their form was assimilated, as well. Undoubtedly, the Azerbaijani language's business style developed based on this language's vocabulary and grammatical structure.

\section{RESULTS AND DISCUSSION}

When talking about economic texts' language, it is necessary to pay attention to its stylistic features and its terminological vocabulary. The problems of the system of economic terms can be shown the as followings: the naming of scientific concepts and their main trends, the interdisciplinary synonymy and interrelation of the system of terms and the entry of terms from one system to another, the origin and development of an individual system of terms, internationalization of terms, etc. Some researchers use the term "special language". For example, as the select language of economics, author [2] notes the following: hotel business language, management language, trade language, agricultural language, construction language, banking language, financial language, transport language, production language, etc.

According to [6] a particular language is characterized as a language created by a specific association and used by a group of people within a specific profession. The below stated can be indicated as the examples of the most used economic terms in the Azerbaijani language: Economic terms: aval, agent, arbitration, assortment, asset, auditor, banker, banco, beta coefficient, stock exchange, boycott, binder, business, bonanzas, bank, penalty, charter, debtor, deficit, debt, devaluation, dumping, denunciation, subsidy, valuation, invoice, factoring, fiscal, collateral, customs tax, hyperinflation, holding, inflation, treasury, mortgage, double exchange rate, import, indenture, importer, creditor, trade commissioner, grant, pawnshop, brand, fraud, exchange rate, neophyte, payment ratio, transfer credit, patent, rent, estimate, tax, tender, transit, turnover, inspection, voucher, guarantee, etc. 
According to [9], "...the country's current economic development since the period of independence can be divided into two stages. The first is a period of economic chaos or recession that spanned 1991-1995 years. The second, the period of macroeconomic stability and dynamic economic development, began in 1996".

There are many economic terms of European origin in the Azerbaijani language, and, as a rule, before being acquired, they underwent phonetic changes. They were transferred to the Azerbaijani language through the Russian language. Indeed, if the Azerbaijani language had a direct relationship with European languages, these terms would have undergone different phonetic changes. During phonetic acquisitions through the perception of a linguistic unit's sound image, the lexical unit's sound composition's substitution occurs. In this regard, the researchers distinguish the following types of substitutions: a) the principle of sound convergence - the successive replacement of two similar sounds; b) the sound divergence - imitation of one sound by two sounds; c) the simple substitution - the same sound of the sounds of the transmitting language and the assimilating language. Each derived word is subject to phonetic changes; the following factors can be cited as the reason for this: 1) the differences in the phonetic system and alphabet; 2 ) orthographic rules; 3 ) the effect of the transmitting language, etc.

The changes in economic life, the establishment of market relations in the country's economy, and the expansion of entrepreneurial activity create the basis for developing economic terminology and enriching the terminological system. From this perspective, the economic terms that change more quickly in terminology reflect economical relations and mark emerging concepts. The notions are more active in terms of enrichment opportunities. In turn, this creates the conditions for a comparative study of these qualitative and quantitative changes in the terminological base of our language in this area. The transition of the post-Soviet space countries to a new economic relations system, they're joining the international financial and trade relations, and taking successful steps to master the globalized world's economic relations in this context has led to the fundamental changes in the terminology of these languages. Even though the interlexemes expressing the terminology of economic relations in the globalized world constitute heaviness, during this period, the language of the Turkic-speaking republics of the former USSR also included the economic terms formed under the influence of the Ottoman Turkish language. In recent decades, the tendency to use Turkish languages, mostly modern Turkish, as a source in enriching our language terminology has become widespread. Even in some cases, the modern Turkish language's influence has conditioned Turkish terms' parallel use in the terminological system with traditional Russian-European acquisitions. We also visually observe this process in economical texts.

We see the same process in the Ottoman Turkish language. Although the nationalization of economic terminology in the Turkish language began in the early XX century, this process spread in the 30s of the XX century. Author [12] writes: "The Turks, who have been involved in trade throughout history and have created and used many terms throughout history, have unfortunately lagged in the problem of expressing economic and trade terms in the Turkish language during the Republican period. The terms used in the banking system today are enough to describe this situation" [12]. Author [7] expressed the same opinion: "In the first years of the Ottoman state and our Republic, the words of Arabic and Persian origin, which were in the Turkish language, were largely Turkicized by the Language Revolution and the process of assimilation. However, the problem of words that have been or are being transferred from Western languages to our language has started".

The acquired economic terms in the modern Azerbaijani language can be classified from different points of view. Among them, the principle of which language the term acquired belongs to occupies one of the main places. Based on this principle, we can divide the acquired economic terms in the languages we study into two groups:

1. The economic terms derived from Arabic and Persian languages.

2. The economic terms derived from European languages.

The first group of acquisitions forms a more ancient layer, and it has a high level of semantic equivalence against the background of specific phonetic differences. The second group of acquired terms, almost the absolute majority, consists of terms with interlexeme status. Their repetition, more or less, in the language of any nation involved in the mechanisms of the economic integration of the globalizing world is inevitable. Hundreds of economic terms of Arabic and Persian 
origin are used in the modern Azerbaijani language. For example, customs, commodity, demand, investment, service, reduction, economy, duty, insurance, compensation, export, finance, savings, stock, inheritance, import, export, turnover, economy, etc.

The economic terms of Arabic origin have a significant weight in the Azerbaijani language. There is no field of science in which Arabic origin is not used, including the economy. The I component of some economic terms of Arabic origin has the Arabic meaning, and the II component usually has other linguistic origins. For example, turnover balance, commodity exchange, economic boycott, counterfeit promissory note, etc. Sometimes the component I is in another language, and component II is of Arabic origin. For example, environmental impact, operational time, water supply, winning savings, etc. Sometimes terms of Arabic origin are used with lexical and grammatical suffixes of Turkish origin - for example, inheritance lease, preferred stock, etc. Within the years of independence, the transfer of Arabic origin to our language is not observed.

One of the linguistic layers of modern Azerbaijani language among economic terms is European origin acquisitions. Author [10] writes: "The expansion of international relations in recent years, the existence of commonalities in ideology, democratic progress, and integration to Europe also affect the sources of language enrichment. At present, European origin terms are one of the main sources for the emergence of terms in the Azerbaijani language. Because of the functionalization of the concepts related to new technologies, especially computer science, telecommunications, cybernetics, space technology, the process of acquiring terms and the concepts in our language, as in almost all civilized languages of the world, is mainly based on the international coordination". Most of the economic terms in the modern Azerbaijani language are words of European origin. This type of economic terms can be grouped in the source language: 1 - the words acquired from the Latin language. For example, agent, agrarian, asset, depreciation, apparatus, article, etc. The words acquired from the French language. For example, arbitration, advance, bankruptcy, profile, etc. 3. The words acquired from the English language. For example, a brand, budget, charting, distributor, dealer, voucher, etc. 4 . The words are taken from the Greek language. For example, port, mechanism, basis, crisis, mortgage, parameter, technique, etc. 5. The words are taken from the German language. For example, promissory notes, valve, formular, etc. 6 . The words acquired from the Italian language. For example, pawnshop, account, balance, currency, etc.

It should also be noted that, until 1991, the economic terms were translated into Azerbaijani through the Russian language. Still, since the years of independence, they have been transferred directly due to direct economic relations.

The Azerbaijani language's economic terms are etymological of Turkish derivation; morphologically simple, derivative and complex structure. While the terms of Turkish origin are in the minority among the terms of simple economic structure, it can be said that the Turkish terms predominate among terms of derivative structure. Terms of the economy of Turkish origin, structured in the Azerbaijani language, are widely used. In the modern Azerbaijani language, most of Turkish origin's economic terms are formed in phrases, and such economic terms are widely used.

When talking about the lingo-semantic features of economic texts, it is necessary to talk about abbreviations. One of the unusual structures observed in economic terms in the Azerbaijani language is abbreviations. The economic terms that emerged based on the acronym can be grouped as indicated below according to the presence of the language to which they belong and perform the function of transmission: a) the abbreviations based on word combinations in the source language. This type of abbreviations occurs based on the capital letters of unique names and expressions in the source language; b) the abbreviations formed based on word combinations in the receptor language. These abbreviations are not based on specific names and expressions in the source language but specific names and expressions in the target language. The economic terms of abbreviated character can be grouped according to the principle of compilation as follows: 1 ) referring to initial letters; 2) referring to the combination of the first vowel and consonant sounds of compounds; 3) the mixed-type abbreviated economic terms referring to both the initial letter and the first sound of words in a compound. We can indicate the following examples of economic abbreviations in the Azerbaijani language: AİB - Avropa İqtisadi Birliyi (European Economic Community); ASC - Açıq Səhmdar Comiyyəti (OJSC - Open Joint Stock Company); ASİB - Asiya-Sakit Okean İqtisadi Birliyi (APEC - Asia-Pacific Economic Cooperation); BVF 
- Beynəlxalq Valyuta Fondu (IMF - İnternational Monetary Fund), etc.

\section{CONCLUSION}

Adaptation of the country's economy to the world standards, the formation and strengthening of the market economy relations, providing a wide range of entrepreneurial activity, foreign investments determine the Azerbaijani's continuous and steady development economy.

The process of globalization, which covers the whole world, is manifesting itself more broadly in the field of economic relations.

Economic integration and globalization stipulate the rapid development and enrichment of terminology. Just in such conditions, there is a great need for economic correspondence and the preparation of texts related to the economy, promoting the study of such texts' language.

At the end of our research, we concluded that economics texts are more business-like than functional. The economic texts that reflect business style characteristics also reflect scientific style characteristics since every economic text is also rich in economic terms.

The use of terms is considered a key indicator of scientific style. Therefore, it would not be correct to attribute economic texts to a purely business or scientific style. The style of economic texts is formed at the intersection of two functional styles.

\section{REFERENCES}

1. Arnold, I. V. (1973). The stylistics of modern English Language (stylistics of decodification). Leningrad: Prosveshenie.

2. Babenko, O. V. (2011). Linguistic Aspects of the Economic Term System. Scientific Bulletin National University of Life and Environmental Sciences of Ukraine, 159, 33-45.

3. Brandes, M. P. (1983). The stylistics of the German language. Moscow: Vyshaya shkola.

4. N. d. (1996). Business correspondence in English and Russian languages. Budapest: APA.

5. Guliyeva, A. (2015). Economic terms in modern Turkish and Azerbaijani languages (Doctoral thesis). Baku.

6. Kageura, K. (2001). The Dynamics of Terminology: A Descriptive Theory of Word Formation and Terminological Growth. Philadelphia: John Benjamin's Publishing Company

7. Karahan, A. (2010). Turkish Language. Language and Literature Journal, 700, 540-550.

8. Mammadov, M. (Ed.). (2004). Issues of native language and culture of speech. Baku: Nurlan.

9. Movsumov, J. (2016). Economic Vocabulary. Retrieved from https://achiqkitab.aztc.gov.az/Books/Read/2377/Iqtisadi-Luget-MovsumovC?sa=X\&ved=2ahUKEwib6sadqo_nAhWyx4UKHeuWBB4QFjAOegQIARAB

10. Sadigova, S. (2015). Formation and development of terminology in the Azerbaijani language. Baku: Elm.

11. Vinogradov, V. V. (1965). Stylistics. The theory of poetic speech. Poetics. Moscow: Academy of Sciences of the USSR.

12. Zulfikar, H. (2010). Turkish Language Journal with Articles on Term. Turkish Journal of language and Literature, 700, 486-491. 